\title{
한국어판 네이메헨 설문지
}

(Korean Version of the Nijmegen Questionnaire)

\section{[기본사항]}

\begin{tabular}{|c|c|c|c|c|c|}
\hline 성별 & 남 & & & 나이 & 세 \\
\hline 작성일시 & 년 & 월 & 일 & & \\
\hline
\end{tabular}

\section{[작성방법]}

1. 본 설문지는 개인의 증상을 체크하여 호흡실조를 평가하기 위한 설문지입니다.

2. 설문지는 총 16 문항입니다.

3. 정답이 있는 문항이 아니기 때문에 자연스러운 마음가짐으로 응답해주시면 됩니다.

4. 아래의 0점 5점의 설명 중에서 본인의 증상에 제일 가깝다고 생각되는 칸에 $\sqrt{ }$ 표시를 하면 됩니다.

5. 시간제한은 없으나 어느 한 문항을 너무 오래 생각하지 않는 것이 좋습니다. 
아래 문항들은 평소(오늘을 포함하여 최근 1 주일 이내) 자신이 느끼는 몸의 상태에 대한 질문입니다. 해당항목에 체크 $(\sqrt{ })$ 를 해주십시오.

\begin{tabular}{c|c|c|c|c}
\hline 0점 & 1점 & 2점 & 3점 & 4점 \\
\hline $\begin{array}{c}\text { 전혀 나타나지 } \\
\text { 않는다. }\end{array}$ & $\begin{array}{c}\text { 아주 가끔 } \\
\text { 나타난다. }\end{array}$ & 가끔 나타난다. & 자주 나타난다. & $\begin{array}{c}\text { 매우 자주 } \\
\text { 나타난다. }\end{array}$ \\
\hline
\end{tabular}

\begin{tabular}{|l|l|l|l|l|l|}
\hline \multicolumn{1}{|c|}{ 설문항목 } & 0 & 1 & 2 & 3 & 4 \\
\hline 1. 가슴부위 통증 & & & & & \\
\hline 2. 긴장된 느낌 & & & & & \\
\hline 3. 시야가 흐릿함 & & & & & \\
\hline 4. 현기증 (어지럼증) & & & & & \\
\hline 5. 혼란스러워 이해나 판단이 어려운 느낌 & & & & & \\
\hline 6. 숨(호흡)이 점점 더 빨라지거나 깊어짐 & & & & & \\
\hline 7. 숨(호흡)이 짧음 & & & & & \\
\hline 8. 가슴이 조이는 느낌 & & & & & \\
\hline 9. 윗배 더부룩함 (팽만감) & & & & & \\
\hline 10. 손가락이 따끔거리는 느낌 & & & & & \\
\hline 11. 숨을 깊게 못 쉼 & & & & & \\
\hline 12. 손가락이나 팔이 뻣뻣함 & & & & & \\
\hline 13. 입 주위가 조이는 (당기는) 느낌 & & & & & \\
\hline 14. 손이나 발이 차가움 & & & & \\
\hline 15. 심장이 두근거림 & & & & \\
\hline 16. 불안한 느낌 & & & & \\
\hline
\end{tabular}

